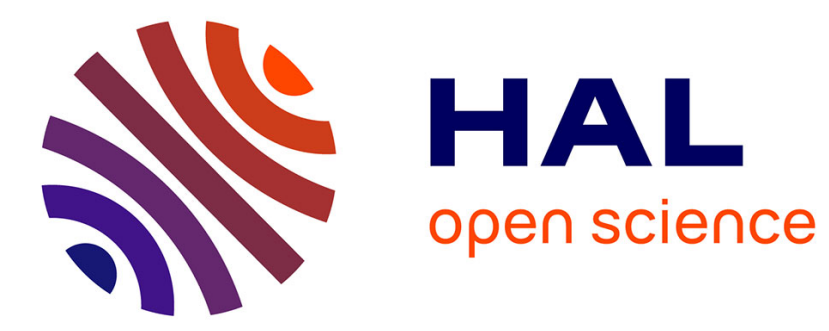

\title{
Quantification and modality: Intransitive ba sentences Robert Iljic
}

\section{To cite this version:}

Robert Iljic. Quantification and modality: Intransitive ba sentences. Space and Quantification in Languages of China, , pp. 141-163, 2015. hal-03083452

\section{HAL Id: hal-03083452 https://hal.science/hal-03083452}

Submitted on 19 Dec 2020

HAL is a multi-disciplinary open access archive for the deposit and dissemination of scientific research documents, whether they are published or not. The documents may come from teaching and research institutions in France or abroad, or from public or private research centers.
L'archive ouverte pluridisciplinaire HAL, est destinée au dépôt et à la diffusion de documents scientifiques de niveau recherche, publiés ou non, émanant des établissements d'enseignement et de recherche français ou étrangers, des laboratoires publics ou privés. 


\title{
QUANTIFICATION AND MODALITY : INTRANSITIVE BA SENTENCES Robert ILJIC (CNRS/EHESS)
}

\begin{abstract}
In Chinese, the sentence form in which the direct object occurs immediately after the preposition $b a \check{~ a n d ~ b e f o r e ~ t h e ~ v e r b ~ i s ~ k n o w n ~ a s ~ ' p r e t r a n s i t i v e ~ c o n s t r u c t i o n ' . ~ H o w e v e r, ~ b a ̆ ~ d o e s ~}$ sometimes occur with intransitive verbs. What is more, the $b a ̆$ noun phrase, which is generally definite, is in this case often preceded by the classifier $g e$, associated with indefinite reference. This particular arrangement, which can be traced back to vernacular báihuà texts, is now relatively rare.

It is shown that in such a configuration, as in all pretransitive constructions, $b a ̆$ marks the patient, even if the latter is the subject of an intransitive verb. Moreover a certain agentivity is bestowed upon the noun in topic position, before $b a ̆ a$, which may amount to a mere desire to avert an unpleasant event, such as the death of a close relative. Ultimately, the purpose of placing $g e$ in front of a proper or a uniquely determined common noun is not to count, that is, express quantity, but rather to emphasize quality. By referring to an individual occurrence as a member of the notional class denoted by the noun, one highlights the property which defines its elements (e.g. the father insofar as he is a father). Hence the specific modal coloration distinctive of this pattern.
\end{abstract}

Keywords: quantification, modality, discourse/pragmatics, typology, Chinese

\section{INTRODUCTION ${ }^{1}$}

My aim in the present study is to explore the relationship between quantification and modality understood as 'modal space'. Definiteness and indefiniteness involve universal operations of quantification. As for modality, it is fundamentally a spatial category.

This article focuses on the modal effects produced by the indefinite quantification of nouns having a definite reference in Chinese. Authors such as Culioli (1985), Talmy (1988), Sweetser (1990), Fauconnier (1994), and others have observed that modality is related to space, insofar as it refers to a subjective space constructed by and centered on the speaker. This is consistent with the classical definition of modality as reflecting « the attitude of the speaker towards what he is saying » (Lyons 1974 :307). In more abstract terms, modality necessarily means considering things from a distance. This follows from the fact that the speaker is exterior to his utterance. The analogy with the ordinary physical space is quite straightforward. In order to appreciate a painting, one must step back (the beholder must be exterior to what $\mathrm{s}$ /he beholds). The same applies to modality. The speaker is able to make value judgments only because $\mathrm{s} / \mathrm{he}$ is exterior to what $\mathrm{s} / \mathrm{he}$ is saying. Modality is intrinsically linked with this status of exteriority and detachability. In a nutshell, modality boils down to space and presupposes distance.

The issues addressed here are closely tied up with the question of classifiers (cf. Fu Jingqi 'The status of classifiers in Tibeto-Burman languages'), verbal quantification (cf. C. Lamarre 'Chinese semelfactives') and location in space (see Feng Shengli's paper on prosodically motivated localizers in Classical Chinese, and Yao Ruoyu's paper on the inclusion spatial relationship in contemporary Chinese).

Generally speaking, the $b a ̆$ construction, which is the main topic discussed in this article, involves agentivity, that is, makes reference to the 'agent-patient' relationship. ${ }^{2}$ The 'agentpatient' relationship and its grammatical and syntactic expression (e.g. 'voice') are one of the 
key issues in interpretation of sentence structure. According to Zhang (2009), our understanding of the agent largely depends on pragmatic and discourse factors (cf. chap. 2).

Zhang's greatest innovation is to consider the specification of the semantic (thematic) roles 'agent' and 'patient' as a dynamic process. Traditionally, the agent-patient relationship has been understood as a static -if not primitive- notion, having a connection only with the valency of the verb. Zhang takes a fresh look at this problem, pointing out multiple factors that may influence the level of agency. He introduces the concepts of 'typicalness, representativeness' (diănxíngxìng) and 'constructional meaning' (jùshì yǔyi), and sets out to examine the possible effects of these notions on both the agent/patient meaning and syntactic variation.

He contends that the status of 'agent' is not always predictable from the predicate-argument structure. Other considerations, in particular the speaker's viewpoint, must be taken into account. Even if a constituent has the requisite qualities, these may not suffice to establish it as a full-fledged agent, especially if they do not accord with the speaker's point of view and feelings. That's why he develops the concept of 'weak agent' (ruò shishì ). For Zhang, 'agent' is not a primitive term but a construct.

The noun phrase placed in front of the verb by means of the preposition $b \check{a}$ is semantically a patient. The referent of the bă noun phrase is handled or dealt with, i.e. disposed of, that's why Wang Li (1979[1947]:160) called the bă construction chǔzhishì 'disposal form'. On historical development, see Peyraube 1985. The bă noun normally corresponds to the direct object of a transitive verb and, as emphasized by Henne et al. (1977:154), Li \& Thompson (1989:465), Fang (1992:324), etc., has a specific or definite reference (ding zhǐ). Yet bă sometimes occurs with intransitive verbs. Consider the following :

\section{(1) Tā bă ge fùqin š̀-le.}

<he-BA[PREP]-GE[CL]-father-die-VS>

'He lost his father.' [literally 'He (suffered) his father to die (on him).']

This sentence raises two problems :

(a) the noun occurring in topic position is not the agent of the action affecting the patient, indeed, the sentence does not mean that 'he killed his father (i.e. caused him to die)' ;

(b) since füqin 'father' has a definite reference ('his father'), what's the classifier ge used for ? In order to explain this paradox, we need to confront the operations underlying the markers $b \check{a}$ and $g e$ with the meanings conveyed by sentences such as (1). This sentence is remarkable in that it exhibits three characteristics at once : co-occurrence of $b a$ with an intransitive verb, cooccurrence of ge with a 'definite' noun, apparent non-agentivity of the subject. Some of these points have been tackled separately by authors like Frei (1956-57), Grootaers (1953-54), Lü (1984[48]), Teng (1975), Audry-Iljic \& Iljic (1986), Zhang (2009), etc. My purpose here is to investigate the complex interaction of all these factors, relying when appropriate on the work of my predecessors.

Most of major grammars of Chinese quote instances of the intransitive $b \breve{a}$ construction. What is striking is the semantic unity of the examples. They all seem to refer to actions that are detrimental to the subject (or the speaker). This modal connotation is shared by the examples recorded in linguistic surveys and attested in classic novels (ex. 12-18). The lack of diversity does not mean that the construction has gradually fallen into disuse. Rather, it implies that it is relatively rare because the meaning it conveys is very specific.

Modality is defined as expressing the attitude of the speaker towards what s/he is saying (Lyons 1974, Palmer 2001, Portner 2009). In the case under consideration the modal meaning is one of detrimentality and contrariness (bù rúyì 'not as one wishes'). The speaker resorts to 
this structure for pragmatic reasons (Recanati 2004), its occurrence presupposes special contexts.

Between 1941 and 1943, Grootaers conducted an in-depth survey at Xicetian near Datong in Shanxi Province. It was a long-term investigation using the method of indirect questioning and based on a large and representative sample of population. Grootaers (1953) noted the relative scarcity of this structure, due to the fact that it appears in a limited number of situations, which is consistent with my observations.

\section{A GENERAL SURVEY OF THE FACTS}

Let us first take a look at examples cited in grammars and linguistic studies. Scholars who treat this question when they discuss the $b a ̆$ construction focus on either intransitivity or the co-occurrence with the classifier $g e$.

Chao (1968:343-44) draws attention to apparent cases of indefinite reference consisting of a pretransitive with $g e\langle\mathrm{CL}\rangle$ or $y \bar{l} g e\langle$ one-CL $\rangle$ before the object, where something quite definite is referred to.

(2) Tā bă ge píbāo diū-le.

<he-BA-GE-wallet-lose-VS>

'He lost his wallet.' (Chao $1968: 344)$

(3) Tã bă ge zhàngfu š̌-le, kěshì bù jiǔ yòu jià-le ge zhàngfu.

<she-BA-GE-husband-die-VS-but-NEG-for a long time-again-marry-VS-CL-husband>

'She (suffered) her husband to die (on her), -she lost her husband, but before long she married another husband.' (Chao 1968 :344)

Note that in the first sentence we have a formally transitive verb (di $\bar{u}$ 'lose, mislay'), and in the second an intransitive verb ( $s \check{I}$ 'die'). According to Chao (1968:344), 'the advanced position of the object, brought about by the pretransitive, has a stronger effect than the presence of the word $g e$ or $y \bar{l} g e$ in deciding the definiteness of reference.'

Here are two more examples of $b \check{a}$ with an intransitive verb :

(4) bă ge zéi păo-le.

<BA-GE-thief/burglar-escape/flee-VS>

'allowed the burglar to escape' (Chao 1968 :345)

(5) bă ge füqin š̆-le

<BA-GE-father-die-VS>

'lost one's father' [suffered the loss of one's father] (Chao 1968 :345)

Chao argues that in (4) and (5) bă has a causative meaning 'causes to' or 'allows to'.

The authors of Xiàndài hànyǔ xūcí lìshì (1982:65) quote a similar sentence, containing both an intransitive verb and ge modifying a proper noun :

(6) Gōngshè chéngli-le, bă ge Lǔ lăo năinai lè de hé-bu-lǒng zuĭ. <commune-found-VS-BA-GE-Li-old-grandmother-joyful-DE-close-NEG-bring togethermouth>

'The establishment of the commune made grandma Li so happy that she could not stop smiling.' 
Zhu (1982:187) gives another instance when, in the section on $b \check{a}$, he addresses the issue of the co-occurrence of $g e$ with a proper noun :

(7) Piānpiān yòu bă ge Lăo Wáng bìngdăo-le. <contrary to expectations-again-BA-GE-Lao Wang-be down with an illness-VS> 'That (a man such as) Lao Wang should be bedridden!'

Lü et al. (1980:49) contrast two intransitive bă sentences, one with ge and the other without ge, both specified semantically as bù rúyì 'not in accordance with one's wishes, not going the way one wants, the opposite of what one wants' :

\section{with ge}

(8) Zhēn méi xiăngdào, bă ge dàsăo š̌-le.

<really-NEG-expect sth to happen-BA-GE-eldest brother's wife-die-VS>

'Who would have thought that (a woman such as) the sister-in-law would die !'

\section{without ge}

(9) Piānpiān bă Lăo Lǐ bìng-le.

<contrary to expectations-BA-old-Li-fall ill-VS>

'To think that Lao Li has fallen ill !'

N.B. This modal connotation is highlighted in the translation(s).

Liu et al. (1983:477) group under the heading bù rúyì 'not as one wishes' sentences with verbs expressing disappearance. They observe that such sentences are used mainly in the spoken language.

(10) Zěnme bă ge tèwu păo-le?

<how-BA-GE-secret agent/spy-escape/flee-VS>

'How could (such a prisoner as) that spy be allowed to run away?!'

The person referred to is determined in the context (definite reference).

(11) Tā piānpiān yòu bă ge màozi méi le, chūqu duó lěng a!

$<$ he-contrary to expectations-again-BA-GE-hat-be without-hat-LE-go out-how !-cold-FP>

'Once again, he just had to find himself without his hat, it's so terribly cold outside !'

Although the verb méi 'not have', equivalent to méi yŏu 〈NEG-have>, is formally transitive, it should be noted that it is not an action verb, but rather a sort of stative verb with a strong locative meaning. Both yǒu and méi express the idea of location, respectively, 'is located relative to, there is' and 'is not located relative to, there is not' ${ }^{3}$ Méi is therefore pseudotransitive, and behaves more like an intransitive verb. As a result, in conjunction with $b a ̆$ involving agentivity, méi can only be construed as referring to a change of state, hence the meaning of 'disappearance'. Liu et al. (1983 :477) draw attention to this fact by pointing out that between the verb of the predicate and the noun introduced by $b a ̆$ 'there is no conceptual verb-object relationship' (méi yǒu yìniàn shàng de dòng-bìn guānxi). Note also that the subject of the sentence is non-agentive and has no influence over the action (change of state). In his his articles on ge (1984[1944] and ba (1984[1948]), Lü Shuxiang quotes examples culled from classic novels written in the vernacular (baihua) of Qing times, the most recent Lăo Cán yóu jì 'The travels of Lao Can' dates from the beginning of the twentieth century (1904-1907). Let us examine some of these sentences : 
(12) Zhĭ zhèi ȳi jù, bă ge Jiăng Píng xià-le yī tiào.

<only-this-one-sentence-BA-GE-Jiang Ping-frighten-VS-one-jump/leap>

'This sentence alone made (such a man as) Jiang Ping jump with fright.'

(Sān xiá wǔ yì, chap.109.6, Lü 1984 :164)

(13) Bă ge Zhā ng gū niang xiū de wú-dì-zì-róng.

<BA-GE-Zhang-girl-ashamed-DE-can find no place to hide oneself (for shame)>

'This made (a person such as) Miss Zhang feel so embarrased that she didn't know where to put herself.' (Ernü yingxióng zhuàn, chap. 9.24, Lü 1984 :192)

(14) Bă ge Lì Wán hé Ž̀ Juān kū de sì-qù huó-lái.

<BA-GE-Li Wan-and-Zi Juan-cry-DE-hovering between life and death>

'This made Li Wan and Zi Juan cry themselves half dead.'

(Hóng lóu mèng, chap. 98.8, Lü 1984 :192)

(15) Bă ge Shā Lóng hē de mìngdìng-dàzuì.

<BA-GE-Sha Long-drink-DE-be dead drunk>

'That made Sha Long drink himself to death.' (Sān xiá wǔ yì, chap. 109.2, Lü 1984 :192)

(16) Bă ge Chǔ dàniángzi máng-le ge shǒu-jiăo-bù-xián.

<BA-GE-Chu-aunt-busy-VS-CL-hand-foot-NEG-idle>

'This kept Aunt Chu so busy that she was perpetually on the move.'

(Ernü yìngxióng zhuàn, chap. 17.4, Lü 1984 :192)

(17) Piān yòu bă Fèng yātou bìng-le.

<contrary to expectations-again-BA-Feng-maidservant-fall ill-VS>

'And to crown it all, the maidservant Feng had to fall ill.'

(Hóng lóu mèng, chap. 76.2, Lü 1984 :194)

(18) Jiă lăo'er jì bă ge dà érzi š̌-le, zhèi èr érzi biàn chéng-le ge băobèi.

$<$ Jia-old man-already-BA-GE-elder son-die-VS-this-younger son-then-become-VS-CLtreasure>

'Old man Jia, having lost his elder son, cherished the younger as if he were a treasure.'

(Lăo Cán yóu jì, chap.15.3, Lü 1984 :194)

Wang Huan (1984:31) also gives examples drawn from classic novels in the vernacular :

(19) Bă Xīmen Qìng chī de mǐngdǐng-dàzuì.

<BA-Ximen Qing-eat-DE-be dead drunk>

'That caused Ximen Qing to get dead drunk during the meal.'

(Jin píng méi, chap.1, Wang Huan 1984:31)

(20) Bă Zhōu xiānsheng xiū de liăn shàng hóng yī kuài bái yı̄ kuài.

<BA-Zhou-Mr-ashamed-DE-face-on-red-one-CL-white-one-CL>

'That made Mr. Zhou feel so ashamed that his face flushed and turned pale by turns.'

(Rúlín wàishř, chap. 2, Wang Huan 1984:31) 
(21) Zěnme bă ge Qíng Wén jiějie yě méi le.

<how-BA-GE-Qing Wen-elder sister-also-there is not-FP>

'How come even Elder sister Qing Wen isn't here ?!' (Hóng lóu mèng, chap. 79)

(22) Dào bă ge Xiāng Líng jí de liăn zhàng tōng hóng.

<but-BA-GE-Xiang Ling-angry-DE-face-swell-very red>

'But this irritated Xiang Ling so much that his face swelled and went crimson.'

(Hóng lóu mèng, chap. 120, Wang Huan 1984 :31)

Note that in the above sentences, including those with the transitive verbs $h \bar{e}$ 'drink' and $c h \bar{\imath}$ 'eat', bă introduces the subject of the action and not the object.

The examples taken from famous novels like Hóng ló mèng may give the impression of being literary. ${ }^{4}$ However, all scholars are unanimous in thinking that this construction belongs to the spoken language. ${ }^{5}$ This is consistent with the observations made by Grootaers during his extensive fieldwork on the initial $b a ̆$ in a Shanxi dialect. Spoken evidence he gathered is similar in every respect to the data derived from texts in the written vernacular. For example :

(23) Bă ge eèxiăož̀ š̆-le.

<BA-GE-second son-die-VS>

'That second son (of his) died.' (Grootaers 1953-54 : 43)

(24) Bă nèi ge hăo rén jiù š̌-le.

$<$ BA-that-GE-good-man-then-die-VS>

'That such a good man should die.' (Grootaers 1953-54 : 43)

(25) Bă liăng ge nüzi tóng š̌-le.

<BA-two-GE-daughter-together-die-VS>

'Both his daughters died.' (Grootaers 1953-54: 44)

(26) Bă fángzi tā-le.

$\langle$ BA-house-collapse-VS>

'(After the rain) the house collapsed.' (Grootaers 1953-54 : 44)

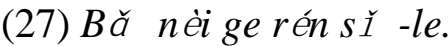

$<$ BA-that-GE-man-die-VS>

'That man died.' (Grootaers 1953-54 : 45)

(28) Bă tā füqin š̀-le.

$\langle$ BA-he-father-die-VS>

'His father died.' (Grootaers 1953-54 : 46)

This is only a small part of Grootaers' corpus. I leave aside $b \check{a}$ sentences with a predicative complement expressing extent (Li \& Thompson, 1989 :626-27), since we have already seen several such examples above $(6,13,14,15,19,22)$.

Mullie (1932:184) gives two examples of the intransitive $b \check{a}$ construction collected in Jehol (Rèhé region) :

(29) Tà ba ge niángmenr š́-le.

$<$ he-BA-GE-wife-die-VS>

'His wife is dead.' / 'He lost his wife.' 
(30) Wǒmen bă ge bărtou hái bìng-le.

<we-BA-GE-workmaster-also/too-fall ill-VS>

'Besides our workmaster fell ill.'

Frei (1956/57 :43) compares the last sentence to example (17) taken from Hóng lóu mèng. He remarks that this type of construction, in which intransitive bing 'fall ill' co-occurs with $b a$, is also current in the modern Peking dialect, where one can hear :

\section{(31) Bă tā diē bing-le.}

<BA-he-father-ill-VS>

'His father is ill.' (Frei $1956: 44)$

There is considerable evidence to show that this pattern is peculiar to Northern Mandarin. It is attested in northern dialects (including that of Peking) and in báihuà (the written vernacular).

\section{THE RESPECTIVE FUNCTIONS OF BA AND GE}

I now turn to the co-occurrence of $b \check{a}$ with an intransitive verb as well as the meaning of the noun preceded by the classifier $g e$.

\subsection{Bă with an intransitive verb}

Such sentences are particularly incongruous if one considers the $b a$ construction ' $\mathrm{S} b a \mathrm{VO}$ ' as being derived from the base structure SVO, which would imply that the verb must be transitive. Recall that the possibility of moving the object by means of the preposition $b a$ before the verb was traditionally used as the criterion for determining whether a verb is transitive or not (Jahontov 1957, Yahongtuofu 1958). Viewed in this perspective, it is rather disconcerting that $b a ̆$ should introduce the subject of an intransitive verb. Zhu (1982:186-89), among others, has shown that this position is untenable. This is particularly striking when the verb has two objects, as in :

(32) Tā bă júzi bāo-le pí. $<$ he-BA-orange-peel-skin>

'He peeled the orange.' [literally: What he did to the orange was to peel its skin.]

The sentence corresponds to the pattern $\mathrm{S} b \check{a} \mathrm{O}_{1} \mathrm{~V} \mathrm{O}_{2}$, where $\mathrm{O}_{1}$ (the referent of the $b \check{a}$ noun phrase) represents the entity affected by the action of the verb, the one to which something happens, and $\mathrm{O}_{2}$ the grammatical direct object of the verb. An agent (whether expressed or unexpressed) produces a change in $\mathrm{O}_{1}$, that is, causes it to change in some way through the action V. The role of the grammatical direct object is essentially to specify or qualify this change. $\mathrm{O}_{2}$ indicates what precisely the action $\mathrm{V}$ does to $\mathrm{O}_{1}$. As noted by Li \& Thompson (1989:472), there is often a relationship of possession between $\mathrm{O}_{1}$ and $\mathrm{O}_{2}$, although this is not indispensable. The only way to express that is by using $b a$, there is no corresponding base structure without bă. Cf. also Jin (1997 :422).

Another such case is the intransitive $b \check{a}$ construction. If $b \check{a}$ is deleted, the noun becomes the subject of an intransitive verb. Here, too, it is impossible to reconstruct the pattern SVO in which the noun previously introduced by bă would be the object of the verb. Zhu $(1982: 188)$ gives an illustration of this : 
(33) Bă fànrén păo-le.

$<$ BA-prisoner-flee-VS >

'The prisoner (was allowed to) flee.'

Without bă, fànrén 'prisoner' becomes the subject of păo 'to flee' and not its object :

(34) Fànrén păo-le.

<prisoner-flee-VS>

'The prisoner fled.'

Zhu (1982:188) concludes that the $b a ̆$ construction is in fact related, not to the SVO sentences, but to the sentences whose subject zhǔyǔ is non-agentive. Indeed, bă cannot introduce a noun indicating an agent (an entity acting upon another entity), which rules out the subject of a transitive verb, the so-called ergative subject (cf. Lyons $1974: 352$, Primus 1999). ${ }^{6}$ The only possible candidates left are the subject of an intransitive verb and the object of a transitive verb. That's exactly what we observe in Chinese. The referent of the bă noun phrase must be non-ergative. According to Zhu (1982:185), the primary function of bă is to introduce the patient' (y̌nchü shoushì ), i.e. the entity which is affected by the action of the verb. One should make this statement even more forceful. Since there is only one marker $b a ̆$, it must fulfil the same fundamental function in all cases, including those that appear as exceptions to the rule. Audry-Iljic \& Iljic (1986:46) have shown that in a subjectless sentence such as :

(35) Bă wǒ qìš̀-le.

<BA-I-be angry.die-LE>

'That made me terribly angry.'

the presence of $b \check{a}$, as opposed to its absence, signals that the person who gets angry is actually brought into this state by something else (a situation, a fact), left unexpressed here. Compare with (36) below :

(36) Wǒ qìš̌-le.

$<$ I-be angry.die-LE>

'I am terribly angry.'

Lü Shuxiang (1984:192[1948:124]) observed that in certain bă sentences comprising an intransitive verb (mostly expressing feelings) the verb takes on a causative meaning and becomes transitive. This phenomenon is particularly frequent with verbs followed by a complement of extent (degree) introduced by de or $g e$ as in :

(37) Dāngxià xian bă Dèng Jiǔgōng lè-le ge pāi-shǒu-dă-zhăng.

<instantly-at first-BA-Deng Jiugong-happy/joyful-VS-GE-clap one's hands>

'That instantly made Deng Jiugong so happy that he clapped his hands.'

(Ernü yingxióng zhuàn, chap. 19.11, Lü 1984 :192)

This type of sentence is fairly common and quite productive (cf. examples $6,13,14,16,19$, 20, 22).

In summary, two types of intransitive bă construction are to be distinguished. The first one is characterized by the verb being followed by a complement of extent/degree or by $g e$ (see above), the second includes all the other intransitive $b a \check{~ s e n t e n c e s . ~}$ 
The sentences of the first type have a causative meaning. The action is done to such an extent that the result is the state expressed by the stative clause introduced by $d e$ or $g e$. This group poses no problem. The referent of the bă noun phrase, i.e. the patient, is affected by the action of the verb, the intensification of the action causes a qualitative change in the patient.

The second type is more intriguing. It has two major characteristics : (a) the connotation bù rúyì 'contrary, not as one wishes', (b) a limited number of compatible verbs. For example :

(38) Qùnián yòu bă ge lăobànr š̌-le.

<last year-again-BA-GE-husband or wife (of an old married couple)-die-VS>

'To crown it all her husband (his wife) died last year!'

(Sun et al., $1995: 264)^{7}$

This kind of sentence is already reported in Courant (1914) :

(39) Yòu bă tā diē š̀-le.

<again-BA-he-father-die-VS>

'And on top of everything else, his father died.'8

(a) The strong modal connotation bù rúyì is the most prominent feature of this class of sentences. It is frequently reinforced by the adverbs yò 'on top of everything else' and piānpiān 'contrary to expectations'. This connotation is absent from the utterances with a complement of extent/degree (see above). However, what is common to all intransitive bă sentences is that the subject has no control over the situation.

(b) the number of verbs that occur in the second group is extremely limited : $s \grave{l}$ ' die' comes first, followed by bing '(fall) ill' and păo in the sense of 'run away, escape, flee'. It goes without saying that death, illness and escape (flight) always mean a great loss to the subject (speaker) and are regrettable.

In this connection, note that Mullie proposes for the sentence Tā bă ge niángmenr š̆-le. 'His wife is dead' (ex. 29 above) yet another translation which renders the sense of loss more accurately, namely 'He has been deprived of his wife.' Compare with Chao's rendering of example (3) : 'She (suffered) her husband to die (on her), -she lost her husband'.

For his part, Zhu (1982:1987) observes that in examples in which the bă noun phrase refers to the subject of the action, as in :

(40) Bié bă fànrén păo-le.

$<$ NEG-BA-prisoner-flee-VS>

'Do not let the prisoner run away.' (Zhu 1982 :187)

and

(41) Qùnián yòu bă lăobànr š̌-le.

<last year-again-BA-husband or wife-die-VS>

'To crown it all her husband (his wife) died last year!' (Zhu 1982 :187),

the verb is intransitive and usually marks a disappearance (xiāoshī).

In this respect, (40) and (41) are comparable to sentences with pseudo-transitive verbs expressing the loss or disappearance of the 'object', such as examples (2) and (11) above containing the verbs diū 'lose' and méi 'not have (there is not, be without)' respectively.

Here are two other examples with méi : 
(42) Ȳ̇ zhuăn yăn de gōngfu, bă ge màozi méi le. <one-twinkling of an eye-DE-time-BA-GE-hat-not have-LE> 'In a twinkling of an eye, my hat was lost.' (Mullie 1937 :275)

(43) Zěnme hūrán bă ge Qíng Wén jiějie yě méi le ? <how-suddenly-BA-GE-Qing Wen-elder sister-also-not have-LE> 'How come even Elder sister Qing Wen suddenly vanished ?!'

(Hóng lóu mèng, chap. 79, Grootaers 1953/54 :55, Wang Li 1979 :171, Shen J. 2002 :394)

As indicated earlier, although méi (yǒu) 'not have (there is not, be without)' is formally transitive, it actually marks a state (location) and not an action. By the same token, the subject

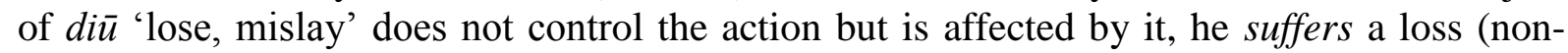
intentionality).

The parallel made by Chao (1968) and Liu et al. (1983) between intransitive and (pseudo-) transitive $b \check{a}$ sentences is quite justified. Significantly, in the transitive examples - just as in their intransitive counterparts of the tā bă ge füqin š́-le type - , it is the insertion of ge into the $b \check{a}$ noun phrase that intensifies the feeling of great or cruel loss.

\subsection{Bă plus ge}

The classifier ge can modify nouns with unique reference : either proper nouns or common nouns referring to entities identified in the context, like fùqin 'father' in example (1).

(44) Tā zěnme bă ge Lăo Lĭ dézuì-le ? <he-how-BA-GE-Lao Li-offend-VS>

'How come he offended (a man such as) Lao Li ?!'

It is claimed that the noun introduced by $b \check{a}$ must be definite, otherwise it cannot appear in this construction. If we accept this assumption, then we have to explain why in some cases $b \check{a}$ is followed by $(y \bar{\imath})$ ge or by $y \bar{\imath}$ 'one' plus another classifier, which is not especially rare. In fact, Liu et al. (1983:469) pointed out that $(y \bar{l})$ ge may refer to one particular entity, a certain person or thing, but which the speaker need not or is unable to specify.

(45) Gāngcái wǒ bă yī ge háizi pèngdăo-le.

<a moment ago-I-BA-one-GE-child-bump into.topple-VS>

'I've just knocked a child down.'/ 'I’ve just run a child over.' (Liu et al. 1983 :469)

[It is a question of a given child, posited existentially, not just any child whatsoever.]

(46) Lăo Mă cóng nù de shūjià shàng bă ȳ̄ běn shū názǒu-le, wǒ méi kàn shūmíng. <Lao Ma-PREP-you-DE-bookshelf-on-BA-one-CL-book-take.go away-VS-I-NEG-see-title> 'Lao Ma took away a book from your bookshelf, I didn't see the title.' (Liu et al. 1983 :469) [Again, it is a matter of one particular book, a certain book.]

See also Li Ying-che (1974 :207), Ding Shengshu (1979 :95), Wang Huan (1984 :25-28, 1985), Lu Jianming \& Ma Zhen (1985 :203-205), Audry-Iljic \& Iljic (1986 :22-23), Song Yuzhu (1995 :354-357), Shen Jiaxuan (2002:391-395), etc.

The inescapable conclusion is that the $b a$ noun phrase refers to something given, that is, posited in the context. Bra gives existential status to what is denoted by N. This case is encountered frequently in texts such as do-it-yourself instructions, recipes and so on, when the 
materials or ingredients are not listed at the outset, but introduced progressively as the task advances. For example :

(47) Bă yī zhī pīngpāngqiú fàng zài hézi de zuǒ shàngjiăo, [...]

<BA-one-CL-ping-pong ball-put-be located-box-DE-left-upper corner>

'Place a ping-pong ball in the left upper corner of the box, [...]' (Ertóng shídài 1985.4 :43)

(48) Bă yī gēn dàizi duizhé, zhé huán xiàng shàng, wò zài zuǒ shǒu zhōng.

<BA-one-CL-ribbon-fold in two-bend/fold-loop-towards-up-hold-be located-left-hand-in> 'Fold a ribbon in two, the loop upwards, and hold it in your left hand.'

(Ertóng shídài 1985.4 :44)

We are dealing with a given ping-pong ball, a given ribbon. This is reminiscent of the way objects are posited in mathematical problems : let ABCD be a rectangle, given an isosceles triangle, it is assumed that..., suppose that..., (let us) take it that..., take... Asserting the existence of something (existential quantification) is consistent with the etymology of bă, namely 'hold, grasp, take'.

The problem of the classifier $g e$ in the sentences in hand is not so much that it occurs between $b \check{a}$ and the noun (there are other examples), but rather that it modifies something that is unique, the only one of its kind (unique reference). In order to ascertain the role of $g e$, we shall compare two identical sequences, one without and the other with CL :

(44') Tã zěnme bă Lăo Lĭ dézuì-le ? <he-how-BA-Lao Li-offend-VS>

'How come he offended Lao Li ?'

and

(44) Tā zěnme bă ge Lăo Ľ̀ dézuì-le?

<he-how-BA-GE-Lao Li-offend-VS>

'How come he offended [even] a man such as Lao Li ?'

(7’) Piānpiān yòu bă Lăo Wáng bìngdăo-le.

<contrary to expectations-again-BA-Lao Wang-be down with an illness-VS>

'That Lao Wang should be bedridden!'

and

(7) Piānpiān yòu bă ge Lăo Wáng bìngdăo-le.

<contrary to expectations-again-BA-GE-Lao Wang-be down with an illness-VS>

'That a man such as Lao Wang should be bedridden !'

Ge adds a modal and contrastive value. The focus is on the fact that this happened to Lao Li or Lao Wang and not to some other person. In other words, ge brings out the contrast between Lao Li or Lao Wang and others. He managed to offend even Lao Li, such a nice and placid man. And it just had to be Lao Wang to be confined to bed with illness, and not someone else. Zhu's $(1982: 187)$ explanation of the presence of $g e$ before a proper noun in example (7) is quite illuminating. Although Lao Wang refers to a definite person, the speaker did not expect that the one who would get ill would be Lao Wang, rather than X or Y. This shade of meaning is made explicit by the adverb pianniān 'contrary to expectations'. Looked at from this angle, Lao Wang is not already known, hence the addition of $y \bar{l}$ ge before. ${ }^{9}$

Here, $(y \bar{l})$ ge is not used for counting (quantification) but to highlight the qualitative aspect : 'even someone like Lao Li', 'and it just had to be a man such as Lao Wang'. That is, Lao Wang is contrasted with persons who do not possess the quality of 'being Wang'. 


\subsection{Theoretical remarks}

According to Lü (1984[44]), who discussed the problem of $(y \bar{\imath})$ ge modifying proper names, (yī) ge Kŏngž̀ <(one)-CL-Confucius> is equivalent to Kǒngž̀ zhème ge rén <Confucius-suchCL-man> 'a man like Confucius'. There is is a striking similarity of means between Chinese and Western languages. In French, un Corneille is understood as 'someone like Corneille, a playwright like Corneille', that is, a person having the qualities characteristic of or peculiar to Corneille. In English, a Shakespeare is interpreted as 'an author like Shakespeare' (Quirk et al. 1974 :160). Cf. also : 'Do you consider yourself a Charles Dickens ?' With proper nouns, both the indefinite article in French or English and $(y \bar{l}) g e$ in Chinese, serve to bring out quality, not quantity. The exact semantic interpretation of the quality involved is, of course, a function of the context.

Quirk et al. (1974:160) indicate that proper names can be reclassified as common nouns, in which case they assume the characteristics of count nouns, in particular, take articles and plural number. Grevisse $(1975: 294)$ observes that, when the indefinite article is employed with proper nouns, it either expresses emphasis or transforms a proper name into a sort of common noun. He also remarks that the indefinite article may produce a similar effect in front of a common noun, underscoring the essential or typical qualities of the person or thing referred to. For example : Quoi, Seigneur! sans l'oü̈r [vous la faites emprisonner] ? Une mère? 'What, my Lord! Without hearing her [you put her in jail] ? A mother?' (Racine, Britannicus, III, 6)

There is no need to go back to Racine, in contemporary French, too, it is possible to say : Elle a perdu un père (un mari, un fils) 'She lost a father (a husband, a son)'. The emphasis is on what a father (a husband, a son) represents for her, and not at all on number (counting). Note that the sentence is about a specific person (her father, etc.), not about an interchangeable element of a class.

Riegel et al. (2009:319) give an interesting example in which a proper name modified by the indefinite article refers to the person named, previously identified and perfectly known in the context, and not to some other person sharing similar qualities : La poétique des ruines devait être illustré par un Chateaubriand (i.e. a writer having exactly the same characteristics as him, that is, actually, Chateaubriand himself). Here, un Chateaubriand refers to Chateaubriand. The class has only one member, Chateaubriand himself !

For the sake of simplicity, consider the referent of a given proper noun, say, Chateaubriand. The class is defined by stating the property (properties) that all its members must satisfy, in this case, the characteristics of Chateaubriand. The defining property of the class here is 'to be Chateaubriand', i.e. 'Chateaubriandness'. Chateaubriand is taken as a qualitative prototype, 'Chateaubriandness' is thus a prototypical quality. Note that the defining property may be taken strictly or broadly, either identical or similar (i.e. comparable) to the qualities that uniquely determine Chateaubriand. In the first case, only one occurrence satisfies the definition, Chateaubriand himself. The class is a singleton, containing one member. That's what we have in the example above, un Chateaubriand refers in the context to Chateaubriand himself, which results in the emphasis on the quality 'to be Chateaubriand'. The defining property of the class, i.e. Chateaubriandness (noted $p$ ), coincides with that of the prototype Chateaubriand (the entity identified in the situation of utterance), this can be written as $\boldsymbol{p}=\boldsymbol{p}$, and corresponds to the intensification of the quality $p$.

In the second case, when the property is taken in the broad sense as being similar or comparable to those of the prototype, the class has more than one member, the persons considered as being like Chateaubriand in some respects. This case corresponds to what Quirk et al (1974:160) call 'reclassification', when proper nouns are treated as common nouns. 
It is thus possible to refer to Chateaubriand by means of un Chateaubriand (cf. Riegel et al. 2009 :319). In this sentence, un Chateaubriand and Chateaubriand refer to a single entity, they are coreferential. It follows that a member of the class defined by the property 'Chateaubriand', noted $p$, is identical to a specific, previously identified person Chateaubriand (possessing the quality 'Chateaubriand'), hence $p=p$, which amounts to enhancing the quality $p$, that is, to what is known as 'high degree'. Note that qualitative intensification has great affinity with exclamatives. Indeed, Culioli (1999:125-134) has shown that exclamatives and 'high degree' are closely related. That's exactly what we observe in the intransitive $b a ̆$ sentences with $(y \bar{\imath})$ ge modifying a proper noun (or a common noun referring to something quite definite in the context), namely emphasis on quality as well as exclamative mood. For exclamatives and 'high degree' (qualitative enhancement), see Culioli (1990:122, 198-201 and $1999: 125-134)$. For a systematic presentation of the operations of quantification (individuation), see Culioli $(1989,1990)$ and Iljic (1994). For definiteness and indefiniteness, see also Strawson 1950 and Haspelmath 1997.

\section{INTERPRETATION OF NOUNS PRECEDED BY BA PLUS GE}

Let us return to Chinese examples. Thus, in example (3), cited by Chao (1968:344), she lost so important a person as a husband. Likewise, in example (18), taken from Lăo Cán yóu jì and quoted by Lü (1984:194), the father who lost such a beloved person as an eldest son, transferred all his affection to the youngest. In both cases, the context shows clearly that the accent is on the quality denoted by the noun.

This 'emphatic' value of the classifier $g e$ is not limited to $b a$ sentences with an intransitive verb. Of course, it is more conspicuous in the case of nouns with unique reference, especially proper names. It is more noticeable in Tā bă ge zhàngfu š́-le 'He lost his father' than in Tã b̆a ge píbāo diū-le 'He lost his wallet', although, according to Chao (1968), in both sentences the classifier carries the same connotation. By emphasizing quality ('a thing such as this'), it stresses the 'preciousness' of the entity affected by the action of the verb (the patient). If the intrinsic importance is not evident, the sentence may be rejected (out of context) just because the thing is not deemed 'valuable' enough. Compare :

(49) ? Nǐ zěnme bă ge gāngbĭ diū-le?

<you-how-BA-GE-pen-lose-VS>

'How come you lost (such an object as) a pen ?'

[about a particular pen]

(50) Nǐ zěnme bă ge zuànshí diū-le?

<you-how-BA-GE-diamond-lose-VS>

'How come you lost (such a precious thing as) a diamond?

[about a given diamond]

Pens are easily mislaid or lost, whereas we usually take great care of diamonds. Zhu Dexi (personal communication) proposed two contexts in which (49) becomes acceptable: (i) referring to a pen of which one is particularly fond ('That you should lose such a pen !'),

(ii) when a pen is urgently needed ('That you should lose such a thing as a pen!'). Another native speaker explained that in example (2), the wallet must have contained important papers or a lot of money ...

Chao (1968:344) contrasted (2) with (51) : 
(2) Tà bă ge píbāo diū-le.

<he-BA-GE-wallet-lose-VS>

'He has lost his wallet.' ['That he should lose a wallet like this !']

(51) Tà diū-le ge píbāo.

$<$ he-lose-VS-GE-wallet>

'He has lost a wallet.'

By normally presupposing an agentive relationship between $t \bar{a}$ 'he' and píbāo 'wallet', $b \check{a}$ imputes the responsibility for the loss of the wallet to the subject. We are dealing here with a 'neutralized' or 'disabled' agentivity (through lack of vigilance, etc.). The subject does nothing to prevent something detrimental from happening. This comes close to Zhang's (2009) notion of 'weak agent'.

In postverbal position, the classifier ge modifying a common noun serves to count (indefinite reference). The spotlight is on quantity. In preverbal position, the $b a$ noun phrase referring to a situationally posited and identified entity (definite reference), ge highlights quality. That is, it underlines what a given object (e.g. a specific wallet) represents qualitatively.

Consider the following :

(52) Tā bă ge zéi păo-le.

<he-BA-GE-thief/burglar-escape/flee-VS>

'That he should allow the burglar to escape !' / 'He let his prisoner escape.'

[such a criminal !] (compare with ex. 4 above)

Zhu Dexi, to whom the example was presented, found it acceptable on one condition : that $t \bar{a}$ 'he' refers to a policeman, 'otherwise the matter does not concern him'. This remark is most illuminating as to the responsibility of $t \bar{a}$. The subject is supposed to have authority over or responsibility for the referent of the bă noun phrase but, nonetheless, lets him do something that defies that authority and gets out of control. In this case, the policeman was in charge of the_prisoner but let him escape (loss of control).

By the same token, in the sentence below the subject is in some sense held 'responsible' for letting the sheep wander away (since he was in charge of the sheep):

(53) Tà bă ge yáng păo-le.

<he-BA-GE-sheep-run away-VS>

'That he should let the sheep run away!'/ 'He let the sheep run away.'

[such an animal as a sheep! such a precious animal ! (emphasis on quality)] ${ }^{10}$

If one could speak to him, the comment would be: 'You should have been more watchful!' As Zhu Dexi pointed out, this sentence does not necessarily imply that there is only one animal, there might be several sheep in the context. What matters is not that one, two or more sheep strayed away, but that such an animal should run away (be lost). This is consistent with the fact that the focus is on quality and not on quantity. After all, one is not supposed to let a sheep wander away without doing anything ! It is ge that makes the qualitative aspect stand

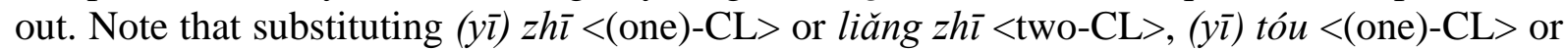
liăng tóu <two-CL> for ge yields a definite numerical value, namely 'one (a given) sheep [the one]', 'the two sheep'. 


\section{CONCLUSION}

After careful scrutiny of the examples, it appears that there is some kind of underlying causal relationship between the subject of the sentence and the referent of the bra noun phrase (the patient). Only with the verb $s \grave{\imath}$ 'die' it seems that no such relation obtains.

The question then arises, what does an utterance such as (1) Tă bă ge füqin š̈-le mean exactly? What are the respective contributions of $b a ̆$ and ge to the overall meaning ?

(i) As in all other cases, bă signals the patient or 'goal', namely the entity which is affected by the action of the verb. Accordingly, the one who is 'acted upon' (i.e. affected by death) is the father. Something - old age, a disease, an accident, etc. - caused him to die, that is, brought him into the state of 'being dead'. Fùqin 'father', the subject of the intransitive verb $s \check{l}$ 'die', is presented here as an 'object' handled, manipulated or dealt with, in a word, disposed of (cf. 'disposal' form).

(ii) $G e$ lays emphasis on the father insofar as he is a father, in other words, it highlights the quality 'be a father'. (Yi) ge refers to an occurrence extracted from a class of occurrences. Given the presence of $b \check{a}$, which presupposes existence, the occurrence in question is situationally anchored (posited existentially). Ge fùqin may be interpreted as 'such a man as a father', in reference to 'his father'. It is because ge implies the construction of a class defined by a certain property (properties) that it can bring out the qualitative aspect. The members of the class are quantitatively separable but qualitatively indistinguishable. In the present case, the defining property which characterizes the elements in the class is '(to) be a father.' Building a class out of a noun with unique reference (a proper name or a definite noun) amounts to highlighting the defining property of the class, i.e. the quality that sets it apart from all the others. It is a differential or contrastive quality.

Lastly, what is the role of $t \bar{a}$ in example (1)?

In the intransitive $b \check{a}$ construction, the relationship between the subject of the sentence and the referent of the $b a \check{~ n o u n ~ p h r a s e ~ i s ~ n o t ~ a g e n t i v e, ~ b u t ~ o n e ~ o f ~ l o c a t i o n . ~ T h e ~ g r a m m a t i c a l ~ s u b j e c t ~ i s ~}$ the locator or experiencer (not the doer), and the referent of the $b a ̆$ noun phrase the locatum. In contrast to the transitive $b a ̆$ construction, which is agentive (the subject is the agent), the relationship of location in the intransitive $b a$ construction may be construed as a sort of 'thwarted agentivity' : the subject cannot prevent something 'harmful' from happening. Unlike the agent, the locator (grammatical subject) is interpreted as 'powerless' (loss of control).

Semantics plays a central role (Recanati 2004). We have, in fact, two superposed semantic relationships, agentivity (agent-patient) and location (locator-locatum). The referent of the bra noun participates in both. It is the pivotal element in this complex structure : at the same time the locatum (relative to the subject of the sentence $t \bar{a}$, the locator/experiencer) and specified as the patient by means of $b \check{a}$. Note that the agent is left unexpressed (the hidden agent). In view of all this, the locator, occupying the position of grammatical subject, is considered as powerless (the non-agent). In conclusion, $t \bar{a}$ is essentially the locator. There is, however, agentivity at work, since the $b a ̆$ noun is explicitly marked as being the patient. The analysis in terms of composition of two relationships forming one complex relationship allows us to unify and account for all the uses of the intransitive $b a ̆$ construction.

The 'powerlessness' of the subject is interpreted as 'something deprived him of (a man such as) his father (lit. 'such a person as a father', with emphasis on quality). As for the verb š́ 'to die', the fact that the referent of the bă noun (fùqin) is located relative to the subject of the sentence $(t \bar{a})$, who is not the agent, suggests nevertheless some kind of implication of the subject in what happened to the father. We are all deeply involved in the death of near relatives and loved ones, and yet powerless. Cf. also Zhang (2009). 
To sum up, in this type of construction the subject has ${ }_{1}$ the action affecting the referent of the $b \check{a}$ noun. Contrary to what is the case in the standard transitive $b \check{a}$ sentences, s/he is not the agent, hence the connotation of powerlessness. With respect to the subject (the speaker), the result of the action amounts to the loss of sb/sth (deprivation, dispossession). The modal meaning produced is one of detrimentality and contrariness. In a way one regrets that one hasn't been able to do anything to prevent such a thing happening. Far from being contradictory, in this construction $b a \check{a}$ and ge have an affinity for each other. Bă in conjunction with the intransitive verb conveys the meaning of loss and powerlessness, while $g e$ highlights the importance of the loss (intensification of the quality $\mathrm{N}$ ).

The only way to achieve valid generalizations about quantification, spatial relations and modality is by a substantial body of carefully conducted empirical studies that examine these phenomena in a wide range of contexts, and from a multidisciplinary perspective. I hope the present study contributes to this end and stimulates more collaborative research within the area of East Asian languages and beyond. Without detailed empirical work on more languages, and especially on less well known and endangered languages, we will never be able to estimate the true range of what is possible in human language.

\section{NOTES}

${ }^{1}$ Abbreviations in glosses are as follows : VS = verbal suffix, $\mathrm{CL}=$ classifier, $\mathrm{NEG}=$ negation, $\mathrm{PREP}=$ preposition, $\mathrm{FP}=$ final particle, $\mathrm{DE}=$ subordinative particle, $\mathrm{S}=$ subject, $\mathrm{V}$ $=$ verb, $\mathrm{O}=$ object, $\mathrm{N}=$ noun .

2 A more detailed discussion of bă can be found in Teng Shou-hsin (1975), Li \& Thompson(1981:463-91), Wang Huan (1984) and Audry-Iljic \& Iljic (1986). More specifically, Fan (2001) disscusses the question of valency, Shen Yang (1997) focuses on the semantic interpretation, while Liu (1997) gives an aspectual analysis of bă. Cf. also Feng (2001) and Zhang (2009).

${ }^{3}$ Semantically, the subject of yǒu/méi (yǒu) is a locator, not an agent.

4 Thus, Wang Li $(1979: 169)$ uses example (17) as an illustration of the intransitive $b \check{a}$ construction in the Modern language.

${ }^{5}$ This was confirmed by Zhu Dexi (November 1986).

6 'Ergativity' is characterized by a formal parallel between the object ('goal') of a transitive verb and the subject of an intransitive verb. The subject of the transitive verb is referred to as 'ergative' whereas the subject of the intransitive verb, along with the object of the transitive verb, are referred to as 'absolutive'. For example, sentences such as The stone moved and The man moved the stone would be analyzed 'ergatively': the subject of the intransitive use of move is the same as the object of its transitive use, the agent of the action is said to be the 'ergative subject'. See Lyons (1974:351-352), Crystal (1991:124-125). 
${ }^{7}$ Zhu (1982 :187) quotes a similar instance without ge, cf. ex. (41).

${ }^{8}$ In his review of Courant's grammar, Maspero (BEFEO, 1914, XIV.9 :78) noted that this construction is 'less strange and, above all, less rare than the authors' comment would suggest'.

${ }^{9}$ Cf. also Grootaers' (1953/54 :43-44) gloss on example (24) above : '(Other people may die, nobody says anything, but when my brother died, they all say :) that such a good man should die !'

${ }^{10}$ Compare with :

Bă ge zhū păo-le.

<BA-GE-pig-run away/escape-VS>

'That the pig should (be allowed to) run away!'

[such an animal as a pig ! (emphasis on quality)]

\section{REFERENCES}

AUDRY-ILJIC Françoise \& ILJIC Robert, 1986. Didactique et linguistique en chinois : les phrases en 'bă' et la nécessaire complémentation du verbe d'action simple. Paris : Institut National de Recherche Pédagogique [INRP].

CHAO Yuen Ren, 1968. A Grammar of Spoken Chinese. Berkeley \& Los Angeles: University of California Press.

COURANT Maurice, 1914. La langue chinoise parlée. Grammaire du kwan-hwa septentrional. Paris-Lyon : Ernest Leroux, A. Rey.

CRYSTAL David, 1991. A Dictionary of Linguistics and Phonetics. Oxford: Blackwell.

CULIOLI Antoine, 1985. Notes du séminaire de D.E.A. 1983-1984. Université de Paris 7 (D.R.L.). Poitiers : Université de Poitiers.

1989. 'Representation, referential processes, and regulation (Language activity as form production and recognition)', in Language and cognition, J. Montangero \& A. Tryphon eds., pp. 97-124. Geneva : Fondation Archives Jean Piaget, Cahier n ${ }^{\circ} 10$.

représentations). Tome 1. Paris : Ophrys.

Tome 3. Paris : Ophrys. 1999. Pour une linguistique de l'énonciation (Domaine notionnel).

DING Shengshu, 1979. Xiàndài hànyǔ yǔfă jiănghuà (Lectures on Modern Chinese grammar). Běijīng : Shāngwù yìnshūguăn.

FAN Xiao, 2001. 'Dòngcí de pèijiè yǔ hànyǔ de bă zì jù' (Valency of verbs and Chinese $b a$ sentence), Zhōngguó yǔwén [ZGYW] 4 :309-319.

FANG Yuqing, 1992. Shíyòng hànyǔ yǔfă (A Functional grammar of Chinese). Běijīng: Běijīng yǔyán xuéyuàn chūbănshè. 
FAUCONNIER Gilles, 1994. Mental spaces: aspects of meaning construction in natural language. Cambridge: Cambridge University Press.

FENG Shengli, 2001. 'Prosodically constrained bare-verb in ba constructions', Journal of Chinese Linguistics [JCL] 29.2 :243-280.

FREI Henri, 1956-57. 'The ergative construction in Chinese: Theory of Pekinese BA3', Gengo Kenkyū 31 : 22-50 and Gengo Kenkyū 32 : 83-115 (Tōkyō).

GREVISSE Maurice, 1975. Le bon usage. Gembloux (Belgique) : Editions J. Duculot.

GROOTAERS William A., 1953-54. «Initial 'pə’ in a Shansi dialect », T'oung Pao 42 :36-69.

HASPELMATH Martin, 1997. Indefinites. Oxford : Oxford University Press.

HENNE Henry, RONGEN Ole Bjørn, HANSEN Lars Jul, 1977. A handbook on Chinese language structure. Oslo - Bergen -Tromsö : Universitetsforlaget.

ILJIC Robert, 1994. 'Quantification in Mandarin Chinese (Two markers of plurality)', Linguistics32.1:91-116.

JAHONTOV Sergej E., 1957. Kategorija glagola v kitajskom jazyke. Léningrad : Editions de l’Université de Léningrad.

JIN Lixin, 1997. 'Bă zì jù de jùfă, yǔyì,yǔjìng tèzhēng' (On the syntactic, semantic and contextual features of sentences with bă), Zhōngguó yǔwén [ZGYW] 6 :415-423.

LI Charles N. \& THOMPSON Sandra A., 1989[1981]. Mandarin Chinese (A functional reference grammar). Berkeley, Los Angeles, London : University of California Press.

LI Ying-che, 1974. 'What does disposal mean? Feature of the verb and noun in Chinese', Journal of Chinese Linguistics [JCL] 2.2 :200-218.

LIU Feng-hsi, 1997. 'An aspectual analysis of bă', Journal of East Asian Linguistics [JEAL] $1: 51-99$.

LIU Yuehua \& PAN Wenyu \& GU Wei, 1983. Shíyòng xiàndài hànyǔ yǔfă (A Functional Grammar of Modern Chinese). Běijīng: Wàiyǔ jiàoxué yǔ yánjiū chūbănshè.

LU Jianming \& MA Zhen, 1985. Xiàndài hànyǔ xūcí sănlùn (A propos des mots vides du chinois contemporain). Běijīng : Běijīng dàxué chūbănshè.

LÜ Shuxiang, 1945[44]. 'Ge zì de yìngyòng fànwéi, fùlùn dānwèicí ȳ̄ zì de tuōluò' (The range of use of ge, followed by a discussion on the omission of yi), Jinlíng, Qílǔ, Huáxi dàxué Zhōngguó wénhuà yánjiū huìkān 5.2 :29-59.

REPUBLISHED IN:

LÜ Shuxiang, 1984 [1955]. Hànyǔ yǔfă lùnwénjí (Papers on Chinese grammar), pp. 145-175. Běijīng : Shāngwù yìnshūguăn. [Enlarged and revised edition]

LÜ Shuxiang, 1948. «Bă zì yòngfã de yánjiū » (Research on the use of bă), Jìnlíng, Qílǔ, Huáxī dàxué Zhōngguó wénhuà yánjīu huikān 8 :111-130.

REPUBLISHED IN :

LÜ Shuxiang, 1984 [1955]. Hànyǔ yǔfă lùnwénjí (Papers on Chinese grammar), pp. 176-199. Běijīng : Shāngùu yìnshūguăn. [Enlarged and revised edition]

LÜ Shuxiang (ed.), 1980. Xiàndài hànyǔ băbăi cí [XHBC] (800 words of contemporary Chinese). Běijīng : Shāngwù yìnshūguăn.

LYONS John, 1974[68]. Introduction to theoretical linguistics. Cambridge: Cambridge University Press.

MULLIE Joseph, 1932 \& 1937. The Structural Principles of the Chinese Language (Dialect of Jehol). Vol I \& Vol. II-III (traduit du néerlandais). Peip'ing: Bureau of Engraving and Printing.

PALMER Frank R., 2001. Mood and modality (2 ${ }^{\text {nd }}$ edition). Cambridge : Cambridge University Press.

PEYRAUBE Alain, 1985. «Les structure en $b a ̆$ en chinois vernaculaire médiéval et moderne », Cahiers de Linguistique Asie Orientale [CLAO] XIV.2 :193-213. 
PORTNER Paul, 2009. Modality. Oxford surveys in semantics and pragmatics. Oxford: Oxford University Press.

PRIMUS Beatrice, 1999. Case and thematic roles: Ergative, accusative and active. Tübingen : Niemeyer.

QUIRK Randolph, GREENBAUM Sidney, LEECH Geoffrey, SVARTVIK Jan, 1974. A grammar of contemporary English. London :Longman.

RECANATI François, 2004. 'Pragmatics and semantics', in Horn Laurence and Ward Gregory (eds.) The handbook of pragmatics. Oxford : Blackwell.

RIEGEL Martin, PELLAT Jean-Christophe, RIOUL René, 2009 [1994]. Grammaire méthodique du français (4-ème édition entièrement revue). Paris : Quadrige/PUF.

SHEN Jiaxuan, 2002. «Rúhé chǔzhì 'chǔzhìshì’? • Lùn bă zì jù de zhǔguānxìng » (Can the disposal construction be disposed of ? On the subjectivity of bă construction in Mandarin Chinese), Zhōngguó yǔwén [ZGYW] 5 :387-399.

SHEN Yang, 1997. "Míngcí duănyǔ de duōchóng yíwèi xíngshì jí bă zì jù de gòuzào guòchéng yŭ yǔyì jiěshì » (The multi-movement form of NPs : the structural process and the semantic interpretation of the bă construction in Chinese), Zhōngguó yǔwén [ZGYW] $6: 402-414$.

SONG Yuzhu, 1995. Yǔyán lùngăo. Běijīng : Běijīng yǔyán xuéyuàn chūbănshè.

STRAWSON Peter F, 1950. 'On referring', Mind 59 : 320-344.

SUN Ruizhen (ed.), 1995. Zhōnggāo jí duìwài hànyǔ jiàoxué dèngjí dàgāng (Cíhuì, Yǔfă). [The teaching programme for intermediate and advanced Chinese (vocabulary and grammar)] Běijīng : Běijīng dàxué chūbănshè.

SWEETSER Eve E., 1990. From etymology to pragmatics (Metaphorical and cultural aspects of semantic structure). Cambridge : Cambridge University Press.

TALMY Leonard, 1988. 'Force dynamics in language and cognition', Cognitive science $2: 49-100$.

TENG Shou-hsin, 1975. A Semantic Study of Transitivity Relations in Chinese. Berkeley: University of California Press.

WANG Huan, 1984. 'Bă' zì jù hé 'bèi' zì jù (Ba sentences and bei sentences). Shànghăi : Shànghăi jiàoyù chūbănshè.

WANG Huan, 1985. «Bă zì jù zhōng bă de bīnyǔ », Zhōngguó yǔwén [ZGYW] 1.

WANG Li, 1979 [1947]. Zhōngguó xiàndài yŭfă (Modern Chinese grammar). 2 Vol. Shànghăi : Zhōnghuá shūjú.

XIANDAI HANYU XUCI LISHI (Function words exemplified and explained), 1982. Beijing : shangwu yinshuguan.

YAHONGTUOFU, 1958. Hànyǔ de dòngcí fànchóu (The category of verb in Chinese). Běijīng : Zhōnghuá shūjú.

ZHANG Bojiang, 2009. Cóng shī-shòu guānxi dào jùshì yǔyì (From agent-patient relationship to constructional meaning). Zhōngguó yǔyánxué wénkù. Běijīng : Shāngwù yìnshūguăn. ZHU Dexi, 1982. Yǔfă jiăngyì (Lectures on Grammar). Běijīng : Shāngwù yìnshūguăn. 


\section{INDEX}

adverb you, 9

agent, agentive, agentivity, agency, 1, 2, 4, 7, 8, 14, 15, 16

'agent-patient' (relationship), 1, 2, 15

$b a$ (preposition), $b a$ construction, $b a$ noun phrase, 1-11, 13-16, 17

$b a+$ intransitive verb, 2

bu ruyi 'not as one wishes', 2, 4, 9

cause to, causative (meaning), causal relationship, 2, 3, 5, 7, 9, 15

class, notional class, $1,9,12,13,15$

classifier ge, 1, 2, 3, 7, 10, 11, 13, 14

co-occurrence, 2, 3, 4, 7

complement expressing extent/degree, $6,8,9$

contrariness, 2,16

contrastive, 11,15

definite, definiteness, definite reference, 1, 2, 3, 10, 11, 13, 15

deprived, deprivation (dispossession), 9, 15, 16

detrimental (harmful), detrimentality, 2, 14, 15, 16

disappearance, 4,9

disposal form (chuzhishi), 2, 15

ergative, ergativity, 8, 16

exclamatives, 13

existence, existential status, 10, 11, 15

French, 12

Given, 10, 11, 12, 12, 14

goal, 15,16

high degree, 13

highlighting, enhancing, 1, 11, 13, 14, 15, 16

indefinite, indefiniteness, indefinite reference, 1, 3, 12, 13, 14

indefinite article, 12

intensify, intensification, 9, 12, 13, 16

intransitive, intransitivity, intransitive verb, 1, 2, 3, 4, 7, 8, 13, 15, 16

intransitive $b a$ construction (sentences), 1,15

locate, locative, location, 1, 4, 10, 15

locator, locatum, 15, 16

loss, suffer a loss, $3,9,10,14,16$

loss of control, no control over, 9, 14, 15, 16

modal, modality, modal space, 1, 2, 4, 9, 11, 16

non-agentive, non-agentivity, non-agent, 2, 4, 8, 15

non-intentionality, 10

patient, 1, 2, 8, 9, 13, 15

pianpian 'contrary to expectations', 9, 11

powerless, powerlessness, 15,16

pretransitive (construction), 1, 3

pseudo-transitive, 4,9

quantity, quantification, $1,11,12,13,14,16$

quality, qualitative, $1,11,12,1314,15,16$

$\mathrm{S} b a \mathrm{VO}, 7$

specific, specific reference, $2,12,13,14$

SVO, 7, 8

transitive, transitivity, transitive verb, 2, 3, 6, 8, 16

two objects $\mathrm{O}_{1}, \mathrm{O}_{2}, 7$

unique reference, 10,11,13, 15

vernacular, written vernacular, baihua, 1, 4, 5, 6, 7

weak agent, 2, 14

(yi) ge modifying a proper noun, 3, 4, 10, 11, 12, 13 